\title{
Intercomparison of an Aerosol Chemical Speciation Monitor (ACSM) with ambient fine aerosol measurements in downtown Atlanta, Georgia
}

\author{
S. H. Budisulistiorini ${ }^{1}$, M. R. Canagaratna ${ }^{2}$, P. L. Croteau ${ }^{2}$, K. Baumann ${ }^{3}$, E. S. Edgerton ${ }^{3}$, M. S. Kollman $^{4}$, \\ N. L. Ng ${ }^{4,5}$, V. Verma ${ }^{5}$, S. L. Shaw ${ }^{6}$, E. M. Knipping ${ }^{7}$, D. R. Worsnop ${ }^{2}$, J. T. Jayne ${ }^{2}$, R.J. Weber ${ }^{5}$ and J. D. Surratt $^{1}$ \\ ${ }^{1}$ Department of Environmental Sciences and Engineering, Gillings School of Global Public Health, The University of North \\ Carolina at Chapel Hill, Chapel Hill, NC 27599, USA \\ ${ }^{2}$ Aerodyne Research, Inc., Billerica, MA 01821, USA \\ ${ }^{3}$ Atmospheric Research \& Analysis, Inc., Cary, NC 27513, USA \\ ${ }^{4}$ School of Chemical and Biomolecular Engineering, Georgia Institute of Technology, Atlanta, GA 30332, USA \\ ${ }^{5}$ School of Earth and Atmospheric Sciences, Georgia Institute of Technology, Atlanta, GA 30332, USA \\ ${ }^{6}$ Electric Power Research Institute, Palo Alto, CA 94304, USA \\ ${ }^{7}$ Electric Power Research Institute, Washington, D.C. 20036, USA
}

Correspondence to: J. D. Surratt (surratt@unc.edu)

Received: 6 November 2013 - Published in Atmos. Meas. Tech. Discuss.: 19 December 2013

Revised: 19 May 2014 - Accepted: 22 May 2014 - Published: 2 July 2014

\begin{abstract}
Currently, there are a limited number of field studies that evaluate the long-term performance of the Aerodyne Aerosol Chemical Speciation Monitor (ACSM) against established monitoring networks. In this study, we present seasonal intercomparisons of the ACSM with collocated fine aerosol $\left(\mathrm{PM}_{2.5}\right)$ measurements at the Southeastern Aerosol Research and Characterization (SEARCH) Jefferson Street (JST) site near downtown Atlanta, GA, during 2011-2012. Intercomparison of two collocated ACSMs resulted in strong correlations $\left(r^{2}>0.8\right)$ for all chemical species, except chloride $\left(r^{2}=0.21\right)$ indicating that ACSM instruments are capable of stable and reproducible operation. In general, speciated ACSM mass concentrations correlate well $\left(r^{2}>0.7\right)$ with the filter-adjusted continuous measurements from JST, although the correlation for nitrate is weaker $\left(r^{2}=0.55\right)$ in summer. Correlations of the ACSM NR-PM 1 (non-refractory particulate matter with aerodynamic diameter less than or equal to $1 \mu \mathrm{m}$ ) plus elemental carbon (EC) with tapered element oscillating microbalance (TEOM) $\mathrm{PM}_{2.5}$ and Federal Reference Method (FRM) $\mathrm{PM}_{1}$ mass are strong with $r^{2}>0.7$ and $r^{2}>0.8$, respectively. Discrepancies might be attributed to evaporative losses of semi-volatile species from the filter measurements used to adjust the collocated continuous
\end{abstract}

measurements. This suggests that adjusting the ambient aerosol continuous measurements with results from filter analysis introduced additional bias to the measurements. We also recommend to calibrate the ambient aerosol monitoring instruments using aerosol standards rather than gas-phase standards. The fitting approach for ACSM relative ionization for sulfate was shown to improve the comparisons between ACSM and collocated measurements in the absence of calibrated values, suggesting the importance of adding sulfate calibration into the ACSM calibration routine.

\section{Introduction}

Atmospheric fine particulate matter with aerodynamic diameters less than or equal to $2.5 \mu \mathrm{m}\left(\mathrm{PM}_{2.5}\right)$ have adverse effects on human health (Dockery et al., 1993), reduce visibility, and play a role in Earth's climate (IPCC, 2013). As a result, there has been an ongoing need to resolve the chemical composition of $\mathrm{PM}_{2.5}$ in order to identify their exact sources, and thus, develop effective control strategies. Organic matter (OM) contributes a major fraction $(25-70 \%)$ of the submicron $\left(\mathrm{PM}_{1}\right)$ mass in the troposphere; however, its sources, 
composition, and atmospheric chemical transformations remain unclear (Jimenez et al., 2009). Inorganic aerosol constituents, such as sulfate $\left(\mathrm{SO}_{4}^{2-}\right)$, nitrate $\left(\mathrm{NO}_{3}^{-}\right)$, ammonium $\left(\mathrm{NH}_{4}^{+}\right)$, and chloride $\left(\mathrm{Cl}^{-}\right)$can also be major components of $\mathrm{PM}_{2.5}$, depending on location and time of year.

Numerous methods for measuring the mass and chemical composition of PM have been put forward, including integrated filter samplers with subsequent laboratory analysis (e.g., Baumann et al., 2003; Solomon et al., 2003b), semicontinuous methods (e.g., Weber et al., 2003a, b; Lim et al., 2003), and real-time instruments (e.g., Gard et al., 1997; Lee et al., 2002; Jimenez et al., 2003). Differences between sampling techniques may occur for a host of reasons, including design, analysis methods, and assumptions used in data reduction. Hence, comparison of new sampling methods with established techniques allows one to determine its suitability for long-term air quality monitoring.

The Aerodyne Aerosol Chemical Speciation Monitor (ACSM, Ng et al., 2011) is designed for reliable long-term operation with minimal user intervention. The key differences between the ACSM and the aerosol mass spectrometer (AMS, Jayne et al., 2000) is that the former lacks a particle beam chopper and uses a relatively lower sensitivity quadrupole and, therefore, data must be averaged over a longer period to obtain sufficient signal-to-noise for quantification. Recent studies showed that the ACSM data are strongly correlated $\left(r^{2}>0.8\right)$ with the Aerodyne highresolution time-of-flight aerosol mass spectrometer (HRToF-AMS) (Ng et al., 2011), time-of-flight ACSM (ToFACSM), and compact time-of-flight AMS (Fröhlich et al., 2013). Comparisons of $\mathrm{SO}_{4}^{2-}$ aerosol showed good correlations between the ACSM and the particle-into-liquid sampler coupled to an ion chromatograph (PILS-IC), and the Thermo Scientific Sulfate Particulate Analyzer (model 5020i), where the ACSM measured $31 \%$ lower for $\mathrm{SO}_{4}^{2-}$ than these two instruments. For $\mathrm{NO}_{3}^{-}$aerosol, the ACSM measured $25 \%$ lower than the PILS-IC (Ng et al., 2011). A recent deployment of the ACSM in Beijing, China, reported a good correlation between the total non-refractory $\mathrm{PM}_{1}\left(\mathrm{NR}-\mathrm{PM}_{1}\right)$ estimated from the sum of all species measured by the ACSM with the $\mathrm{PM}_{2.5}$ measured by the tapered element oscillating microbalance (TEOM), where the ACSM NR-PM 1 reported $64 \%$ of the TEOM PM 2.5 mass (Sun et al., 2012).

The present study compares ambient NR-PM 1 measured by the ACSM with a suite of collocated particle measurements in Atlanta, Georgia. The collocated particle measurements include another ACSM operated by the Georgia Institute of Technology (GIT), continuous $\mathrm{SO}_{4}^{2-}, \mathrm{NO}_{3}^{-}$, and $\mathrm{NH}_{4}^{+}$ measurements operated by Atmospheric Research \& Analysis Inc. (ARA), semi-continuous organic carbon/elemental carbon (OC/EC) measurements, total $\mathrm{PM}_{2.5}$ mass measured by TEOM, integrated $\mathrm{SO}_{4}^{2-}, \mathrm{NO}_{3}^{-}$, and $\mathrm{NH}_{4}^{+}$by particle composition monitor (PCM) developed by ARA, and integrated $\mathrm{PM}_{2.5}$ and $\mathrm{PM}_{1}$ mass measurements based on the Federal Reference Method (FRM).

In the discussion that follows, we first compare individual species (i.e., $\mathrm{OM}, \mathrm{SO}_{4}^{2-}, \mathrm{NO}_{3}^{-}, \mathrm{NH}_{4}^{+}$, and $\mathrm{Cl}^{-}$) and total NR-PM ${ }_{1}$ mass measured from collocated ACSMs during a short period between January and February 2012. Secondly, we compare species measurements (minus chloride) and total mass from the ACSM with organic carbon (OC), $\mathrm{SO}_{4}^{2-}$, $\mathrm{NO}_{3}^{-}, \mathrm{NH}_{4}^{+}$, and $\mathrm{PM}_{2.5}$ from continuous and filter measurements at the Jefferson Street (JST) site during summer and fall 2011. We compare mass from the ACSM with total mass from integrated FRM measurements in three short periods of January-February, April-May, and July 2012. Lastly, we estimate aerosol density from continuous measurements between 17 October to 20 November 2012. From this intercomparison, we have gained more knowledge on continuous ambient aerosol measurements, including the importance of calibrating the routine monitoring aerosol instruments with true aerosol standards rather than gas-phase standards, as well as sulfate calibration as additional routine calibration for the ACSM.

\section{Experimental section}

\subsection{Site description}

Ambient aerosol from Atlanta, Georgia, was collected at the Jefferson Street (JST) site $\left(33.7775^{\circ} \mathrm{N}, 84.4166^{\circ} \mathrm{W}\right)$, which is located in a mixed industrial-residential area about $4.2 \mathrm{~km}$ northwest of downtown Atlanta (Hansen et al., 2003; Solomon et al., 2003a). The JST site is one of the research sites of Southeastern Aerosol Research and Characterization (SEARCH) network that is equipped with a suite of gas, particle, and meteorological measurements. Details of these measurements are described in subsequent sections. The University of North Carolina at Chapel Hill (UNC) ACSM was operated continuously at JST from 27 July 2011 through 21 September 2012, while the GIT ACSM was deployed at this site from 31 January through 29 February 2012 . The period when both ACSMs were collocated at JST is used to evaluate the ACSM performance, and the extended periods in 2011 and 2012 are used to evaluate the accuracy of ACSM measurements against established monitoring network measurements.

\subsection{NR-PM 1 and chemical measurements by the ACSM}

During February 2012, NR-PM 1 was measured by two ACSMs that belong to UNC and GIT, and placed in an airconditioned trailer at JST. Sampling conditions for both ACSMs are described in Table 1. Both ACSMs were operated to scan 150 mass-to-charge $(\mathrm{m} / \mathrm{z})$ ratios of fragmented ions at a rate of $500 \mathrm{~ms} \mathrm{amu}^{-1}$. Vaporizer and heater biases were set at $600^{\circ} \mathrm{C}$ and $100.30 \mathrm{~V}$, respectively, with the bias voltage chosen to maximize the $\mathrm{N}_{2}(\mathrm{~m} / z 28)$ signal. Particle-laden and 
Table 1. UNC and GIT ACSMs sampling setup at the JST site for a short period between January-February 2012.

\begin{tabular}{|c|c|c|}
\hline & UNC & GIT \\
\hline Sampling inlet & $\mathrm{PM}_{2.5}$ cyclone & $\mathrm{PM}_{2.5}$ cyclone \\
\hline Sampling line length & $5.00 \mathrm{~m}$ & $5.00 \mathrm{~m}$ \\
\hline Sampling line diameter & $\begin{array}{l}0.64 \mathrm{~cm} \mathrm{OD} \mathrm{and} 0.46 \mathrm{~cm} \mathrm{ID} \\
\text { stainless steel tube }\end{array}$ & $\begin{array}{l}1.27 \mathrm{~cm} \text { ID for } 1 \mathrm{~m} \text { of length } \\
0.95 \mathrm{~cm} \text { ID for } 4 \mathrm{~m} \text { of length }\end{array}$ \\
\hline Sample drying & $\begin{array}{l}\text { 50-tube Nafion dryer (Perma Pure PD- } \\
\text { 50T-24SS) with } 7.00 \mathrm{~L} \mathrm{~min}^{-1} \text { of sheath } \\
\text { air coming from dry/zero air system }\end{array}$ & $\begin{array}{l}\text { 200-tube Nafion dryer (Perma Pure } \\
\text { PD-200T-12 MPS) running with } \\
0.50 \mathrm{~L} \mathrm{~min}^{-1} \text { sheath air flow (under } \\
\text { vacuum) }\end{array}$ \\
\hline ACSM sampling flow rate & $3.00 \mathrm{Lmin}^{-1}$ & $3.00 \mathrm{Lmin}^{-1}$ \\
\hline $\mathrm{RF}_{\mathrm{NO}_{3}}$ calibration & $3.79 \times 10^{-11}$ & $3.97 \times 10^{-11}$ \\
\hline $\mathrm{RIE}_{\mathrm{NH}_{4}}$ calibration & 6.00 & 4.30 \\
\hline $\mathrm{RIE}_{\mathrm{SO}_{4}}$ fitting & 0.79 & 0.54 \\
\hline $\mathrm{RIE}_{\mathrm{NO}_{3}}$ default & 1.10 & 1.10 \\
\hline $\mathrm{RIE}_{\mathrm{Cl}}$ default & 1.30 & 1.30 \\
\hline RIE $_{\text {Organic default }}$ & 1.40 & 1.40 \\
\hline Reference flow $\left(Q_{\mathrm{cal}}\right.$ in $\left.\mathrm{cm}^{3} \mathrm{~s}^{-1}\right)$ & 1.39 & 1.35 \\
\hline Data acquisition software & ACSM DAQ v1.4.2.2 & ACSM DAQ v1.4.2.5 \\
\hline Data analysis procedure & ACSM Local v1.5.2.0 & ACSM Local v1.5.2.0 \\
\hline
\end{tabular}

particle-free air were sampled interchangeably and averaged over $\sim 30$ min intervals for each measurement. We calibrated the ACSM on site. The ACSMs were calibrated for response factor (RF) and relative ionization efficiency (RIE) using a separate calibration system for UNC and GIT. The resulting values for each instrument are reported in Table 1, and for UNC ACSM, different calibration values were used for different seasons.

Data acquisition software provided by ARI was used to process the measurements to obtain total organic and inorganic (i.e., $\mathrm{SO}_{4}^{2-}, \mathrm{NO}_{3}^{-}, \mathrm{NH}_{4}^{+}$, and $\mathrm{Cl}^{-}$) aerosol mass concentrations. Further details of the concentration calculation are discussed by $\mathrm{Ng}$ et al. (2011) and shown in Eq. (1).

$C_{\mathrm{s}}=\frac{\mathrm{CE}_{\mathrm{s}}}{T_{m / z}} \times \frac{10^{12}}{\mathrm{RIE}_{\mathrm{s}}} \times \frac{Q_{\mathrm{cal}} \times G_{\mathrm{cal}}}{\mathrm{RF}_{\mathrm{NO}_{3}}} \times \frac{1}{Q \times G} \sum_{\text {alli }} \mathrm{IC}_{\mathrm{s}, i}$

Species mass concentration $\left(C_{\mathrm{s}}\right)$ is calculated based on measured ion current (IC in amps) at fragment ion $i$. $\mathrm{CE}_{\mathrm{S}}$ is collection efficiency for species $\mathrm{s}$, and $\mathrm{RF}_{\mathrm{NO}_{3}}$ is instrument response factor from calibration. $T_{m / z}$ is correction for the $\mathrm{m} / \mathrm{z}$ dependent ion transmission efficiency of the quadrupole. $Q_{\text {cal }}$ and $G_{\text {cal }}$ are the volumetric sample flow rate and multiplier gain, respectively, and were determined from calibration, while $Q$ and $G$ are obtained during the measurements. During data processing, calibrated and measured $Q$ and $G$ cancel each other out as part of air beam correction factor (Eq. 2), and no separate correction is applied for flow rate. The air beam correction is applied as it is uncertain whether air beam signal changes due to gain or flow changes.

Air beam correction factor $=\frac{Q_{\mathrm{cal}} \times G_{\mathrm{cal}}}{Q \times G}$
An air beam signal (i.e., $m / z 28$ ) was used to normalize the measurements with respect to instrument measurement sensitivity (i.e., secondary electron multiplier (SEM) gain decay) and sampling flow rate. The effusive naphthalene source was not used due to lower signal-to-noise compared to $m / z 28$ and its dependency on effusion flow and/or background contamination. Moreover, the changes in flow rate need to be accounted for by using the filtered air beam. The ACSM uses a filtered air mass spectrum to account for backgrounds (e.g., $\mathrm{N}_{2}$ and $\mathrm{CO}$ ). These signals will vary with flow rate or slowly desorbing material. Contribution of the slowly desorbing material, however, is generally small compared to the $\mathrm{N}_{2}$ signal at $m / z 28$.

$\mathrm{RIE}_{\mathrm{S}}$ for species $\mathrm{s}$ was determined from calibrations of laboratory-generated aerosols of each species using Aerodyne AMS (Alfarra et al., 2004; Canagaratna et al., 2007). Since the ACSM particle vaporization and ionization source are similar but not identical in design to that of the AMS, there may be differences in RIE values compared to those referenced above. The vaporizer is identical between ACSM and AMS systems. The ion formation chamber in the ACSM is somewhat smaller than in the AMS. The ion source volume in the ACSM is calculated to be $370 \mathrm{~mm}^{3}$ and that of the AMS is $580 \mathrm{~mm}^{3}$. We note, however, that the effective volume is really defined by the electric fields and it is not easily calculated. In both systems the diameter of the extraction into the ion optic lens region is $3 \mathrm{~mm}$. The smaller ion source volume (with tighter spatially distributed electric fields) in the ACSM could result in larger variability of the relative ionization efficiencies with respect to precise particle beam alignment, which is currently being investigated. 
Table 2. Statistics of calibration values obtained from UNC and GIT ACSMs since mid 2011 to early 2013.

\begin{tabular}{lrrrrrrr}
\hline & \multicolumn{3}{c}{ UNC ACSM } & & \multicolumn{3}{c}{ GIT ACSM } \\
\cline { 2 - 3 } \cline { 7 - 8 } Date & $\mathrm{RF}_{\mathrm{NO}_{3}}$ & $\mathrm{RIENH}_{4}$ & $\mathrm{RIE}_{\mathrm{SO}_{4}}^{*}$ & & $\mathrm{RF}_{\mathrm{NO}_{3}}$ & $\mathrm{RIE}_{\mathrm{NH}_{4}}$ & $\mathrm{RIE}_{\mathrm{SO}_{4}}^{*}$ \\
\hline Mean & $4.17 \times 10^{-11}$ & 5.71 & 0.67 & & $3.26 \times 10^{-11}$ & 4.40 & 0.59 \\
1-std deviation & $1.53 \times 10^{-11}$ & 1.01 & 0.09 & & $1.26 \times 10^{-11}$ & 0.38 & 0.04 \\
\% uncertainty & $37 \%$ & $18 \%$ & $14 \%$ & & $39 \%$ & $9 \%$ & $7 \%$ \\
\hline
\end{tabular}

* Sulfate aerosol calibrations were not conducted until early 2013.

The default RIE value for ammonium $\left(\mathrm{RIE}_{\mathrm{NH}_{4}}\right)$ was 3.5; the value obtained from ACSM calibrations was approximately 5.71 (Table 2). The default RIE of sulfate was 1.2, which the real value could be estimated by fitting measured sulfate and predicted sulfate values, derived from $\mathrm{NH}_{4}$,pred equation (Eq. 3). Measured sulfate ( $\mathrm{SO}_{4, \text { meas }}$ ) is sulfate that is measured by the ACSM, while predicted sulfate $\left(\mathrm{SO}_{4, \text { pred }}\right)$ is the estimated value of sulfate from ion balance approach (Eq. 4).

$$
\begin{aligned}
\mathrm{NH}_{4, \text { pred }} & =2\left(\frac{\mathrm{MW} \mathrm{NH}_{4}}{\mathrm{MW} \mathrm{SO}_{4}}\right) \mathrm{SO}_{4, \text { meas }} \\
& +\left(\frac{\mathrm{MW} \mathrm{NH}_{4}}{\mathrm{MW} \mathrm{NO}_{3}}\right) \mathrm{NO}_{3, \text { meas }}+\left(\frac{\mathrm{MW} \mathrm{NH}_{4}}{\mathrm{MW} \mathrm{Chl}}\right) \mathrm{Cl}_{\text {meas }}
\end{aligned}
$$

$$
\begin{aligned}
& \mathrm{SO}_{4, \text { pred }}= \\
& \frac{\mathrm{NH}_{4, \text { meas }}-\left(\frac{\mathrm{MW} \mathrm{NH}_{4}}{\mathrm{MW} \mathrm{NO}}\right) \mathrm{NO}_{3, \text { meas }}-\left(\frac{\mathrm{MW} \mathrm{NH}_{4}}{\mathrm{MW} \mathrm{Chl}}\right) \mathrm{Cl}_{\text {meas }}}{2\left(\frac{\mathrm{MW} \mathrm{NH}}{\mathrm{MW} \mathrm{SO}_{4}}\right)}
\end{aligned}
$$

The previous value of $\mathrm{RIE}_{\mathrm{SO}_{4}} 1.2$ is then multiplied by slope obtained from fitting $\mathrm{SO}_{4}$,pred versus $\mathrm{SO}_{4}$,meas and used as the $\mathrm{RIE}_{\mathrm{SO}_{4}}$ value of this study. UNC ACSM applied fitted $\mathrm{RIE}_{\mathrm{SO}_{4}}$ values of $0.95,0.77,0.79,1.1,0.73$, and 0.44 for summer and fall 2011, winter, spring, summer, and fall 2012 data sets, respectively. Explicit calibration of $\mathrm{RIE}_{\mathrm{SO}_{4}}$ by atomizing $\left(\mathrm{NH}_{4}\right) 2 \mathrm{SO}_{4}$ using the same calibration system from UNC during winter 2013 yielded a value of $0.67 \pm 0.09$ indicating that the fitting approach value $(0.79 \pm 0.22)$ is consistent with the calibrations, with a larger uncertainty (Table 2). We found that $\mathrm{SO}_{4}^{2-}$ percent difference between ACSM and collocated measurement at JST was improved from about $50 \%$ to less than $30 \%$. Therefore, in addition to regular calibration using $\mathrm{NH}_{4} \mathrm{NO}_{3}$, we recommend additional calibration using $\left(\mathrm{NH}_{4}\right)_{2} \mathrm{SO}_{4}$ to obtain an $\mathrm{RIE}_{\mathrm{SO}_{4}}$ value specific for the ACSM.

A CE of 0.5 was used to calculate mass concentration. We used a Nafion dryer to dry ambient air samples; investigation of species-dependent CE (Middlebrook et al., 2012) suggested that CE is not influenced by highly acidic aerosol (Fig. S1 in the Supplement) or ammonium nitrate (Fig. S2 in the Supplement) as provided in the supplemental information. Some measurement periods were excluded from the data analysis due to operational and maintenance issues, such as shutdown during calibrations. Aerosol mass spectrometer uncertainty was estimated 20-35\% (Bahreini et al., 2009) which included CE uncertainty of $30 \%$. A recent study of composition dependent CE parameterization (Middlebrook et al., 2012) has substantially contributed to narrow the uncertainty of AMS, which could be used as a guideline for ACSM accuracy $(\sim 30 \%)$.

\subsection{Chemical constituents measured by integrated and continuous particle measurements at JST site}

Details of the JST site measurements are provided elsewhere (Hansen et al., 2003; Edgerton et al., 2005, 2006). Inlets for particle samplers are mounted on the rooftop of the sampling trailer about $5 \mathrm{~m}$ above ground level. The particle measurements consist of $24 \mathrm{~h}$ filter sampling conducted every third day (daily for $\mathrm{PM}_{2.5}$ and $\mathrm{PM}_{1}$ mass), and of continuous and semi-continuous measurements by instruments placed in an air-conditioned trailer. Integrated, semi-continuous, and continuous $\mathrm{PM}_{2.5}$ measurements are listed in Table 3, and described briefly below. Field blank loadings of JST site measurements are generally insignificant for $\mathrm{SO}_{4}^{2-}, \mathrm{NH}_{4}^{+}$and $\mathrm{OC}$, but can be significant for $\mathrm{NO}_{3}^{-}$and $\mathrm{EC}$ mostly due to loadings at or below detection limit of those components (Edgerton et al., 2005). We emphasize here that the JST site aerosol instruments are based on gas phase detection of aerosol conversion products (e.g., $\mathrm{SO}_{2}$ from $\mathrm{SO}_{4}^{2-}$ and $\mathrm{NO}$ from $\mathrm{NO}_{3}^{-}$), therefore, are calibrated with standard gases instead of directly by particle mass generated from an atomizer combined with scanning electrical mobility sizer (SEMS) mixing condensation particle counter (MCPC) as done for the ACSM.

\section{Particle components measurements}

Details of the semi-continuous and continuous $\mathrm{PM}_{2.5}$ sampling and analysis are provided in Edgerton et al. (2006) and in the supporting information. Briefly, $\mathrm{PM}_{2.5}$ mass is measured continuously using an R \& P Model 1400a/b TEOM operated at $30^{\circ} \mathrm{C}$ to reduce losses of semi-volatile compounds and with main flow rate of $3 \mathrm{~L} \mathrm{~min}^{-1}$. Sample air was pulled through a $\mathrm{PM}_{10}$ inlet followed by a $\mathrm{PM}_{2.5}$ Very Sharp Cut Cyclone (BGI Incorporated) that goes inside the trailer where a multi-tube Nafion drier (Perma Pure) is installed 
Table 3. Summary of integrated, semi-continuous, and continuous $\mathrm{PM}_{2.5}$ analyses at JST.

\begin{tabular}{|c|c|c|c|c|}
\hline Analyte & Instrument & Analytical method & Detection Limit $\left(\mathrm{mg} \mathrm{m}^{-3}\right)$ & Frequency/Time Resolution \\
\hline \multicolumn{5}{|c|}{ Integrated samples } \\
\hline Mass & FRM (Teflon, $47 \mathrm{~mm}$ ) & Gravimetry & 0.2 & daily \\
\hline $\mathrm{SO}_{4}^{2-}$ & PCM1 (Teflon, $47 \mathrm{~mm}$ ) & IC & 0.05 & 3-day \\
\hline $\mathrm{NO}_{3}^{-}$ & PCM1 (Teflon, $47 \mathrm{~mm}$ ) & IC & 0.01 & 3-day \\
\hline $\mathrm{NH}_{4}^{+}$ & PCM1 (Teflon, $47 \mathrm{~mm}$ ) & $\mathrm{AC}$ & 0.03 & 3-day \\
\hline Volatile- $\mathrm{NO}_{3}^{-}$ & PCM1 (Nylon, 47 mm) & IC & 0.02 & 3-day \\
\hline Volatile- $\mathrm{NH}_{4}^{+}$ & PCM1 (Citric acid-coated cellulose, $47 \mathrm{~mm}$ ) & $\mathrm{AC}$ & 0.04 & 3-day \\
\hline $\mathrm{OC}$ & PCM3 (Quartz, $37 \mathrm{~mm}$ ) & TOR & 0.08 & 3-day \\
\hline \multicolumn{5}{|c|}{ Continuous samples } \\
\hline Mass & R \& P 1400a/b TEOM (modified) & Oscillating microbalance & 2.0 & $5 \mathrm{~min}$ \\
\hline $\mathrm{SO}_{4}^{2-}$ & HSPH (modified) & Reduction to $\mathrm{SO}_{2} / \mathrm{PF}$ & 0.4 & $1 \mathrm{~min}$ \\
\hline $\mathrm{NO}_{3}^{-}$ & Thermo Scientific & Reduction to NO/CL & 0.25 & $1 \min$ \\
\hline $\mathrm{NH}_{4}^{+}$ & Thermo Scientific & Oxidation to NO/CL & 0.07 & $1 \mathrm{~min}$ \\
\hline $\mathrm{OC} / \mathrm{TC}$ & Sunset OC/EC Analyzer & Combustion to $\mathrm{CO}_{2} / \mathrm{NDIR}$ & 0.5 & $60 \mathrm{~min}$ \\
\hline
\end{tabular}

Notes: Volatile- $\mathrm{NO}_{3}^{-}$and Volatile- $\mathrm{NH}_{4}^{+}$are collected on back filters as $\mathrm{HNO}_{3}$ and $\mathrm{NH}_{3}$ dissociation on the front filter; IC represents ion chromatography technique; $\mathrm{AC}$ represents automated colorimetry method; TOR indicates thermal/optical reflectance method; PF represents pulsed fluorescence technique; CL indicates ozone-NO chemiluminescence method; HSPH stands for Harvard School of Public Health.

to dry the sample. $\mathrm{SO}_{4}^{2-}$ is measured continuously using a modified Harvard School of Public Health (HSPH) Sulfate Particulate Analyzer. $\mathrm{NH}_{4}^{+}$and $\mathrm{NO}_{3}^{-}$were measured using a three-channel continuous differencing method developed by ARA, Inc. (Edgerton et al., 2006). Total carbon (TC) was semi-continuously measured by a Sunset OC/EC instrument (model 3), which collects particles on a filter. Once collection is complete (after $\sim 50 \mathrm{~min}$ ), the oven is purged with $10 \% \mathrm{O}_{2}$ in $\mathrm{He}$, and then ramped up to a set point of $850^{\circ} \mathrm{C}$ according to the NIOSH 5040 analysis protocol.

Inorganics, OC, and total mass concentrations from the continuous analyzers were adjusted to match the filter-based data via linear regression since the continuous analyzers have been shown to drift over time. New adjustments are applied every $1-2$ months, depending on the stability of the individual analyzer. With respect to carbon measurements, OC is calculated as the difference between filter-adjusted TC and filter-adjusted EC, and OM is estimated from applying an OM/OC ratio of 1.4 (Edgerton et al., 2006).

The component mass loadings from each filter were blankcorrected using SEARCH network-wide average loadings from field blanks, then the corrected loading was normalized by sampling volume. Details of the integrated measurements at the JST site are provided in Edgerton et al. (2005). This study will focus on comparison between ACSM and JST filter-adjusted continuous measurements (Figs. S3, S4 and S5 in the Supplement). Results of intercomparison between ACSM and filter measurements are presented in the supporting information (Figs. S6 and S7 in the Supplement).

\subsection{Total particle mass measurements}

$\mathrm{PM}_{2.5}$ mass concentrations were obtained by several methods during this campaign. Continuous total mass concentrations were obtained with the TEOM (after adjustment to match the integrated PCM-based $\mathrm{PM}_{2.5}$ ). The JST-integrated
$\mathrm{PM}_{2.5}$ values were obtained by adding blank-corrected PCM measurements together with volatile $\mathrm{NO}_{3}^{-}$from PCM nylon, volatile $\mathrm{NH}_{4}^{+}$and volatile $\mathrm{OM}$ from $\mathrm{PCM}$ back filter.

FRM filter samples were collected for $24 \mathrm{~h}$ using dual R \& P Model 2025 sequential FRM monitors to determine both $\mathrm{PM}_{2.5}$ and $\mathrm{PM}_{1}$ mass. $47 \mathrm{~mm}$ diameter Teflon filters ( $2 \mu \mathrm{m}$ pore size) were used for these measurements, and the collection, processing, and analysis of these filters followed FRM protocol (Code of Federal Regulations, 2001). $\mathrm{PM}_{1}$ filters were sampled during three separate sampling periods: January to February, April, and July 2012, representing winter, spring, and summer seasons, respectively.

\subsection{Aerosol density estimation}

Total $\mathrm{PM}_{1}$ volume measurements were obtained using the Brechtel Manufacturing Incorporated (BMI) SEMS equipped with a cylindrical-geometry differential mobility analyzer (DMA) and coupled to an MCPC (Sorooshian et al., 2008). The DMA was set to size particles between 10$1000 \mathrm{~nm}$ in diameter for both up and down scans. Differential mobility analyzer sheath airflow rate was set to $5 \mathrm{~L} \mathrm{~min}^{-1}$ and particles were sampled at $0.5 \mathrm{~L} \mathrm{~min}^{-1}$. Particle volume concentration from each scan was collected every $120 \mathrm{~s}$, and both up and down scans were averaged to get one data point every $4 \mathrm{~min}$ and $30 \mathrm{~s}$, which includes the scanning delay time.

\section{Results}

The ACSM measured about $11.6 \mu \mathrm{g} \mathrm{m}^{-3}$ of OM, $3.2 \mu \mathrm{g} \mathrm{m}^{-3}$ of $\mathrm{SO}_{4}^{2-}$, and $0.61 \mu \mathrm{g} \mathrm{m}^{-3}$ of $\mathrm{NO}_{3}^{-}$during summer 2011. The numbers decreased in the fall 2011, except for nitrate (Table S1 in the Supplement). The ACSM measured chloride on average of 0.02 to $0.04 \mu \mathrm{g} \mathrm{m}^{-3}$ in summer and fall, respectively. 


\subsection{Intercomparison between the UNC and GIT ACSMs}

The UNC and GIT ACSMs were collocated from 10 January to 23 February 2012. Intercomparisons of chemical species between the two ACSMs shown in Fig. 1 indicate strong correlations $\left(r^{2}>0.8\right)$, except for chloride $\left(r^{2}=0.21\right)$. Slopes and intercepts of the linear regression are provided in Table 4 . Weaker correlations of chloride might be due to its low concentration in Atlanta.

\subsection{Intercomparison of ACSM with collocated JST measurements}

Intercomparisons of species and total mass measurements by the ACSM, continuous particle measurements from JST, Sunset OC analyzer (model 3), and TEOM $\mathrm{PM}_{2.5}$ (model $1400 \mathrm{a} / \mathrm{b})$ at the JST site are given in Table 4 for summer (8 August to 14 September) and fall (17 October to 21 December) 2011 sampling periods. Collocated mass and chemical constituent measurements were averaged to the ACSM sampling times to allow for a direct intercomparison. Previous intercomparison studies conducted at the same site have been limited to the summer season (Solomon et al., 2003a); therefore, results from this study could reveal possible aerosol measurements variation across seasons and instrumentation differences in aerosol measurements.

\subsubsection{Species comparison}

ACSM OM is strongly correlated with OC from the Sunset OC/EC analyzer $\left(r^{2}\right.$ values are 0.86 and 0.92 for summer and fall, respectively); the resulting ratios (from the linear regression slopes in Table 4) of OM/OC are $4.85 \pm 0.05$ and $3.85 \pm 0.02$ in summer and fall, respectively. Aerosol Chemical Speciation Monitor OM versus Sunset OC correlations are likely higher since they are both real-time and not affected by storage related losses, such as that from the filter measurements.

$\mathrm{ACSM} \mathrm{SO}_{4}^{2-}$ is strongly correlated with that from JST continuous measurements in the summer $\left(r^{2}=0.84\right)$ and for some periods in the fall $\left(r^{2}=0.83\right.$; September-November); however, the correlation is weaker for some periods in December $\left(r^{2}=0.22\right)$ when JST measured several instances of very high $\mathrm{SO}_{4}^{2-}$ aerosol. Percent differences between the measurements are 4 and $44 \%$ for summer and fall, respectively. These results are close to previous sulfate intercomparisons between ACSM and collocated measurements (slope $=0.95,0.69$, and 0.69, for HR-ToF-AMS, PILS-IC, and sulfate particulate analyzer, respectively) ( $\mathrm{Ng}$ et al., 2011).

For $\mathrm{NH}_{4}^{+}$comparison, correlations are high $\left(r^{2}=\sim 0.8\right)$ and intercepts for both summer and fall are insignificant. Differences between ACSM and JST measurements are $20 \%$ $\left(r^{2}=0.79\right)$ for summer and $51 \%\left(r^{2}=0.76\right)$ for fall.
Table 4. Correlations between the ACSM and the collocated measurements at JST site. Slope and intercept \pm 1 standard deviation from each linear regression correlations are presented.

\begin{tabular}{lcc}
\hline & \multicolumn{2}{c}{ JST Continuous $^{\mathrm{c}}$} \\
\cline { 2 - 3 } & Summer 2011 & Fall 2011 \\
\hline Mass $^{\mathrm{a}}$ & & \\
$r^{2}$ & 0.71 & 0.83 \\
Slope & $1.50 \pm 0.02$ & $2.10 \pm 0.02$ \\
Intercept & $-2.89 \pm 0.31$ & $-4.36 \pm 0.20$ \\
\hline OM vs. OC & & \\
$r^{2}$ & 0.86 & 0.93 \\
Slope & $4.85 \pm 0.05$ & $3.85 \pm 0.02$ \\
Intercept & $-7.34 \pm 0.19$ & $-2.99 \pm 0.09$ \\
\hline SO $_{4}^{2-}$ & & \\
$r^{2}$ & 0.84 & 0.83 \\
Slope & $1.04 \pm 0.01$ & $1.44 \pm 0.02$ \\
Intercept & $-0.73 \pm 0.04$ & $-0.54 \pm 0.03$ \\
\hline NO $_{3}^{-}$ & & \\
$r^{2}$ & 0.55 & 0.81 \\
Slope & $2.14 \pm 0.04$ & $1.77 \pm 0.02$ \\
Intercept & $0.06 \pm 0.01$ & $0.08 \pm 0.02$ \\
\hline NH $_{4}^{+}$ & & \\
$r^{2}$ & 0.79 & 0.76 \\
Slope & $1.20 \pm 0.02$ & $1.51 \pm 0.02$ \\
Intercept & $-0.19 \pm 0.02$ & $-0.61 \pm 0.01$ \\
\hline
\end{tabular}

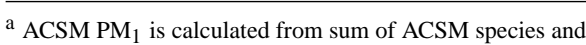
Sunset EC. ${ }^{b}$ For ACSM-to-ACSM comparison, it is OM vs. OM. ${ }^{c}$ JST measures $\mathrm{PM}_{2.5}$ mass and chemical constituents.

Intercomparisons between $\mathrm{ACSM} \mathrm{NO}_{3}^{-}$and JST continuous $\mathrm{NO}_{3}^{-}$result in percent differences of $114 \%\left(r^{2}=0.55\right)$ and $77 \%\left(r^{2}=0.81\right)$ in the summer and fall, respectively. The weaker correlation and larger discrepancy in the summer might be due to the low $\mathrm{NO}_{3}^{-}$loadings and evaporative losses from filters that will be discussed later.

\subsubsection{Total mass comparison}

ACSM PM $\mathrm{PM}_{1}$ mass was determined from the sum of ACSM $\mathrm{OM}, \mathrm{SO}_{4}^{2-}, \mathrm{NO}_{3}^{-}, \mathrm{NH}_{4}^{+}$, and $\mathrm{Cl}^{-}$as well as $\mathrm{EC}$ from the Sunset OC/EC analyzer. The intercomparison of the ACSM $\mathrm{PM}_{1}$ and TEOM $\mathrm{PM}_{2.5}$ shows a good correlation, with $r^{2}$ values of 0.71 and 0.83 , respectively, and discrepancies of 50 and $110 \%$ for summer and fall, respectively (Table 4). As in the speciated ACSM and PCM measurement comparisons, discrepancies in the fall might have resulted from positive biases of species measurements by the ACSM. Since the TEOM measurements are adjusted to match filter mass concentrations, it is also possible that the adjusted TEOM values are lower than the ACSM PM 1 values because of evaporation 

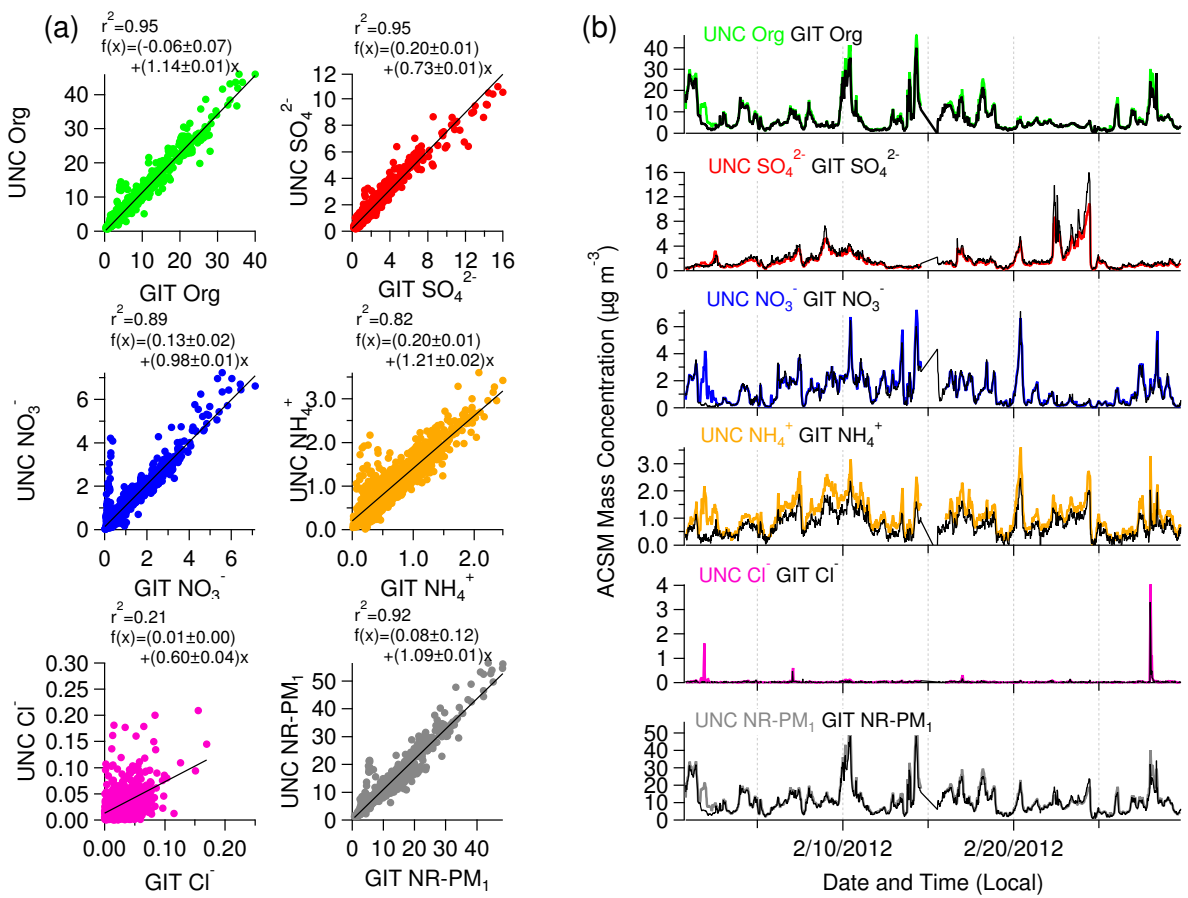

Figure 1. (a) Linear regression correlation and (b) time series plots of organic and inorganic constituents measured by the UNC and GIT ACSMs. ACSM measurements from UNC are colored by species while those from GIT are colored in black.

of semi-volatile organics and nitrates from the filters during storage.

The ACSM data were averaged to the FRM filter sampling times, which was $24 \mathrm{~h}$ (midnight to midnight) during each sampling period. Comparison between the ACSM NR-PM 1 and $\mathrm{FRM} \mathrm{PM} \mathrm{PM}_{1}$ in winter, spring, and summer 2012 shows a good correlation, with $r^{2}$ values of $>0.80$ (Fig. 2), and the mass concentrations differences vary from $10 \%$ in summer to $73 \%$ in winter. For the same period, comparison of ACSM NR-PM 1 and FRM-PM 2.5 shows a good correlation $\left.r^{2}>0.80\right)$. The tighter comparisons during summer $\left(r^{2}>0.8\right)$ compared to winter $\left(r^{2}=\sim 0.6\right)$ might suggest meteorological influence on total mass measurements due to positive bias from filter measurement during colder seasons (Solomon et al., 2003a, b).

\section{Discussion}

\subsection{Intercomparison between ACSM instruments}

Slopes of the linear regression from UNC ACSM vs. GIT ACSM (Table 4) suggest percentage differences of speciated mass concentrations are 4 to $38 \%$ between two independent ACSM measurements. The $\mathrm{SO}_{4}^{2-}$ difference of $25 \%$ can be attributed to uncertainty in the instrument RIE fitting results. The percent uncertainty of the fitting approach is larger $(28 \%)$ than calibration results $(7-14 \%)$ recently conducted at both ACSMs. Larger differences of $\mathrm{Cl}^{-}$measurements
(79\%) are due to its significantly lower concentration in Atlanta during the entire sampling period. This resulted in weaker correlation between the two instruments although both instruments capture similar large peaks of $\mathrm{Cl}^{-}$for some periods.

\subsection{OM/OC ratio}

The OM/OC ratios derived from the regression linear slopes are larger than most $\mathrm{OM} / \mathrm{OC}$ ratios previously reported in the literature. These values are significantly higher than the traditionally used values of 1.6 for urban aerosol and 2.1 for non-urban aerosol (Turpin and Lim, 2001; Lim and Turpin, 2002; Russell, 2003). They are also larger than those found from recent HR-ToF-AMS intercomparisons with the Sunset OC/EC analyzer that report $\sim 1.8$ from September in Pittsburgh (Zhang et al., 2005a), 1.8 and 1.6 from summer and fall in Tokyo (Takegawa et al., 2005), 1.41-2.15 from March in Mexico (Aiken et al., 2008), 2.59 from August in New York City (Sun et al., 2011) and 3.3 from summer in Pasadena (Hayes et al., 2013). Studies in Atlanta also reported a high variability of OM/OC ratio, from 1.23-3.44 in August 1999 (Baumann et al., 2003) and 1.77 in December 1999 to 2.39 in July 1999 (El-Zanan et al., 2009). These suggest variability in $\mathrm{OM} / \mathrm{OC}$ ratios based on location, time and meteorological conditions, and/or that the ACSM is measuring organic mass much higher than it should since it is using AMS-based RIE values for organic (i.e., RIE =1.4) rather than those that have been explicitly measured for ACSM instruments. 

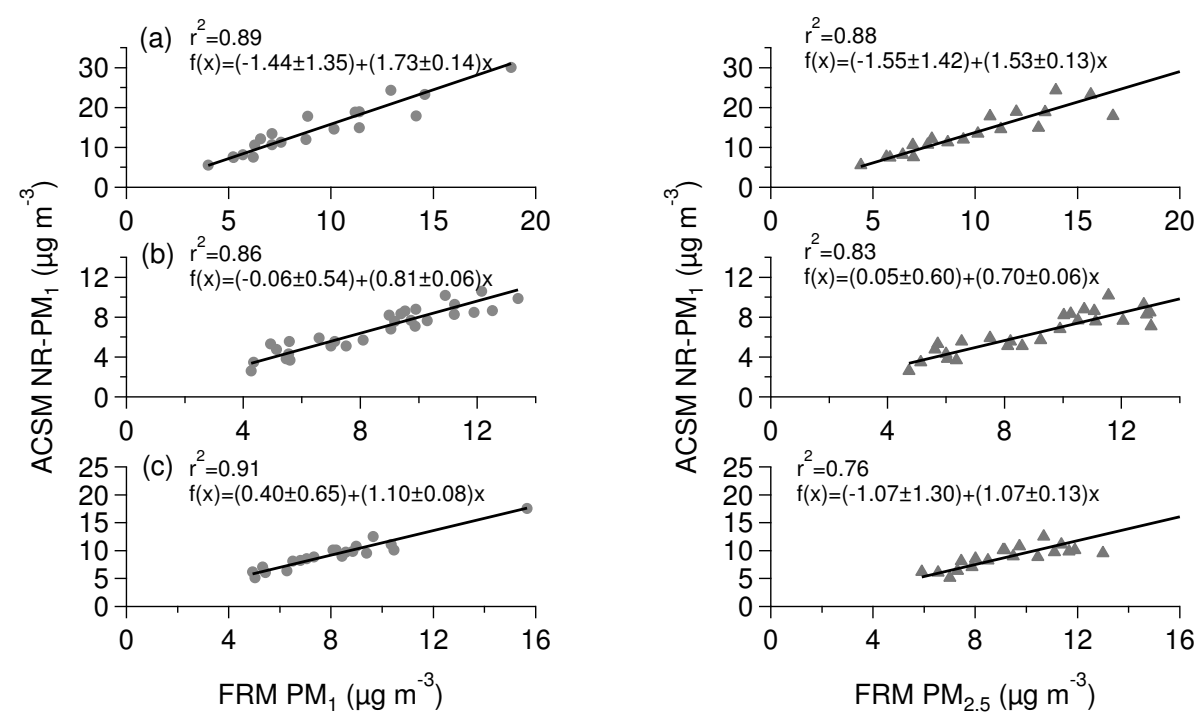

Figure 2. Correlation of ACSM NR-PM1 measurements with those of FRM PM $\mathrm{PM}_{1}$ and $\mathrm{PM}_{2.5}$ methods during (a) winter, (b) spring, and (c) summer 2012, respectively.

The large OM/OC ratios might also be attributed to underestimation of OC due to evaporation of semi-volatile organic compounds (SVOCs) from the Sunset OC analyzer, and/or overestimation of OC due to condensation of SVOC or adsorption of VOC on the filter (Couvidat et al., 2013). This is reflected in a large offset at the Sunset OC (Figs. S4 and S5 in the Supplement). The presence of a denuder on the inlet of Sunset OC/EC analyzer, for example, might cause evaporation of particulate $\mathrm{OC}$ from the collection filter due to repartitioning of SVOC after removal of gaseous organics by the denuder (Grover et al., 2008). Also, $20 \%$ of Sunset OC uncertainty (Peltier et al., 2007) together with ACSM uncertainty might propagate the $\mathrm{OM} / \mathrm{OC}$ ratio.

Overestimation of OM by the ACSM could arise from underestimation of the RIE value of organic species. The RIE values used in this study are based on experiments examining a suite of organic standards using the AMS instrument (Jimenez et al., 2003; Alfarra et al., 2004). Since the two instruments rely on the same vaporizer and ionization conditions (i.e., electron ionization), it was assumed that the RIE values for organics should be similar. However, based on the high $\mathrm{OM} / \mathrm{OC}$ ratios observed from our intercomparison study, sets of authentic organic standards covering a wide range of chemical classes as well as secondary organic aerosol generated from laboratory experiments, such as isoprene-derived secondary organic aerosol (SOA) (Kleindienst et al., 2006; Lin et al., 2012), need to be systematically analyzed in future work in order to determine the RIE value for organics in the ACSM.

The large OM/OC ratios might also suggest photochemically, well-aged, and well-mixed air masses contain particlephase organics that are more oxygenated and less-volatile compared to more stagnant air masses where less polar and more volatile organics can be found possibly due to incomplete photochemical oxidation leading to more labile functional groups and intermediates. An offline polaritybased analysis suggested values of 1.9 to 2.1 for OM/OC ratios due to aging and oligomerization processes in the atmosphere (Polidori, 2008). In addition, water-soluble organic aerosol was observed to have higher $\mathrm{OM} / \mathrm{OC}$ ratios than that of less water-soluble organics, ranging from 2.1-2.3 in the Great Smoky Mountains to 3.3 in downtown Los Angeles (Turpin and Lim, 2001). Furthermore, ratios of 2-3.12 were observed from organic fractions that could not be extracted using organic solvent (Polidori, 2008), indicating that compound-specific polarity might be related to sources of organic aerosol. Therefore, besides overestimation of OM by ACSM as noted above, high OM/OC ratios might indicate that the organic aerosol is more water-soluble in nature.

\section{3 $\mathrm{SO}_{4}^{2-}$ and $\mathrm{NH}_{4}^{+}$measurements variations}

Sulfate measurements from ACSM and the filter show a good trend $\left(r^{2}>0.7\right.$, see Fig. S7 in the Supplement) for the December period, suggesting that the large discrepancies observed between the ACSM and JST data might be caused by some unknown issues with either the JST continuous measurements or ACSM during this sampling period. Both ACSM and continuous measurements show that the slopes of $\mathrm{NH}_{4}^{+}$measured versus $\mathrm{NH}_{4}^{+}$predicted (neutralized) are slightly less than 1 (Fig. S8 in the Supplement). This suggests during both summer and fall 2011, the aerosol was slightly acidic. Investigation of the period where correlation between ACSM and collocated measurement is low in fall season suggest some organic interferences (hydrocarbonlike organic aerosol/HOA) in sulfate fragments, in particular $m / z 81$ (Fig. S9 in the Supplement). 

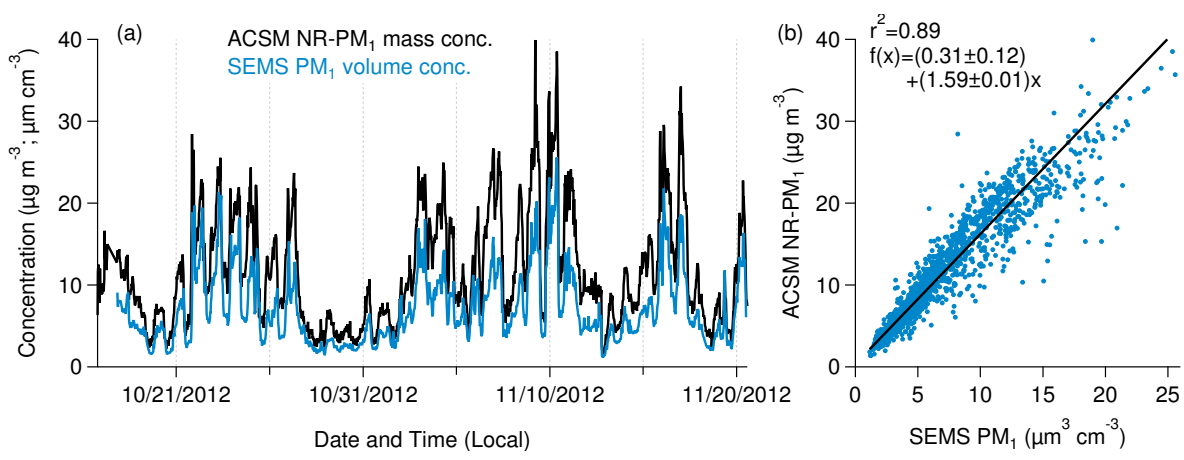

Figure 3. (a) Time series and (b) correlation of total aerosol mass measured by ACSM (NR-PM 1 ) and SEMS DMA/MCPC during period of 17 October to 20 November, 2012. Aerosol density was estimated from the linear regression slope of 1.59 multiplied by 1.10 to account for the $10 \%$ of elemental carbon (EC) component that is not measured by ACSM. This results in estimated aerosol density of $1.75 \mathrm{~g} \mathrm{~cm}^{-3}$.

Previous comparison of $\mathrm{SO}_{4}^{2-}$ measurements from the Thermo Electron 5020 Sulfate Particulate Analyzer with filter-based methods from laboratory and field studies observed good correlations (i.e., slope derived from field study was closer to 1 than that of laboratory study) (Schwab et al., 2006). It should be noted that Schwab et al. (2006) suggested that the slope differences are due to ambient $\mathrm{SO}_{4}^{2-}$ from the field study being catalytically converted to $\mathrm{SO}_{2}$ faster than the laboratory-generated $\mathrm{SO}_{4}^{2-}$. During this study, the $\mathrm{ACSM} \mathrm{SO}_{4}^{2-}$ measurements discrepancies are $4-44 \%$ compared to that of the continuous modified HSPH sulfate analyzer, with the largest difference occurring during colder months (fall season). This difference is within the expected accuracy of the ACSM measurements, but since the JST continuous $\mathrm{SO}_{4}^{2-}$ values are obtained after adjusting to the filter data, the bias could be due to artifacts from the filter data.

\subsection{Discrepancies of $\mathrm{NO}_{3}^{-}$measurements}

ACSM $\mathrm{NO}_{3}^{-}$measurements are based on the measured $m / z 30$ and $m / z 46$ ion signals. Positive biases at $m / z 30$ are possibly due to contributions to this ion from $\mathrm{NO}^{+}$fragments of organic nitrates and/or contributions from organic $\mathrm{CH}_{2} \mathrm{O}^{+}$ions. A detailed investigation of the interference of $\mathrm{m} / \mathrm{z} 30$ is provided in the supplemental section. The relationship of estimated excess signal of $m / z 30$ linked to organic and oxygenated organic aerosol is found to be heteroscedastic. Thus, oxygenated organic species could not be suggested to directly influence nitrate fragments.

The continuous $\mathrm{NO}_{3}^{-}$data are adjusted to the integrated $\mathrm{NO}_{3}^{-}$data, which can impose measurement biases, especially for semi-volatile compounds such as $\mathrm{NO}_{3}^{-}$. Hering and Cass (1999) reported lower aerosol $\mathrm{NO}_{3}^{-}$mass from Teflon filters compared to that from denuded nylon filters. For this study, the PCM filter samples utilized both Teflon and nylon filters downstream of a denuder in order to account for $\mathrm{NO}_{3}^{-}$losses. Previous SEARCH results have compared $\mathrm{NO}_{3}^{-}$ measurements with parallel systems: one with a Teflon prefilter and nylon backup filter (PCM1) and the other with just a nylon filter (PCM2) (Edgerton et al., 2005). Both systems were denuded to remove artifacts of $\mathrm{HNO}_{3}$ and $\mathrm{NH}_{3}$, thus thermodynamics should favor metathesis of $\mathrm{NH}_{4} \mathrm{NO}_{3}$. Summer results showed that PCM1 agreed with PCM2 within $5 \%$ and that $>95 \%$ of the $\mathrm{NO}_{3}$ from PCM1 was on the nylon backup filter. Fall results showed agreement within $10 \%$ and with $>90 \%$ on the nylon filter (Edgerton et al., 2005). While the use of nylon backup filters likely minimized $\mathrm{NO}_{3}^{-}$ losses during sampling, additional losses during filter storage and conditioning before off-line chemical analysis cannot be ruled out and could have contributed to the observed discrepancy.

Changes in meteorological conditions from summer to fall might influence the equilibrium partitioning behavior of nitrogenous compounds. Low temperatures and high relative humidity $(\mathrm{RH})$ in the fall could create thermodynamic conditions that favor the partitioning of gaseous $\mathrm{NO}_{3}^{-}$to the aerosol phase (Hennigan et al., 2008; Rastogi et al., 2011). The fact that the observed $\mathrm{NO}_{3}^{-}$discrepancies are larger in the fall than the summer is consistent with evaporative loss of $\mathrm{NO}_{3}^{-}$from the filter samples and reflected in the filteradjusted continuous data.

In summary, it is unclear if the higher $\mathrm{ACSM} \mathrm{NO}_{3}^{-}$loadings reflect true $\mathrm{NO}_{3}^{-}$levels which include contributions from organic nitrate not captured by $\mathrm{JST} \mathrm{NO}_{3}^{-}$, or if it is from inaccurate subtraction of $\mathrm{m} / \mathrm{z} 30$ originating from oxidized organic aerosol. Also, it is possible the discrepancy may be due to the underestimation of JST $\mathrm{NO}_{3}^{-}$due to volatility losses from the filters which are used to scale the JST $\mathrm{NO}_{3}^{-}$ data. It is likely some combination of all of the above, which cannot be clearly determined from this data set, explains the differences between $\mathrm{NO}_{3}^{-}$measurements.

\subsection{Total mass measurements variations}

$\mathrm{ACSM} \mathrm{PM}_{1}$ is sum of ACSM NR-PM 1 (i.e., organic and inorganics) plus EC measurements from JST site. This study shows that total mass differences between ACSM PM P $_{1}$ and TEOM $\mathrm{PM}_{2.5}$ are $50-110 \%$. Previous intercomparisons of 
the same instruments in summer in Beijing suggested that ACSM NR-PM 1 measured $\sim 30 \%$ less than TEOM $\mathrm{PM}_{2.5}$ (Sun et al., 2012). Since the ACSM PM 1 mass is a sum of species concentrations, the discrepancies in species specific intercomparisons described above result in high discrepancies of $\mathrm{PM}_{1}$ mass. Uncertainties in RIE values, particularly for organic species, may be partly responsible for overestimation of certain species resulting in overestimation of NR$\mathrm{PM}_{1}$ mass. On the other hand, loss of semi-volatile species from the filters (which are used together to adjust TEOM loadings) could also result in lower TEOM PM 2.5 concentration. This is supported by the fact that in fall, when the meteorological conditions favor semi-volatile organic aerosol enhancement, the slope of the ACSM PM 1 to TEOM PM 2.5 is much higher than that in summer (i.e., slope of 1.80 in fall to 1.19 in summer).

Differences between NR-PM 1 masses measured by the ACSM and $\mathrm{PM}_{1}$ mass measured by the FRM method are about $10-73 \%$, with the lowest difference observed in the summer data set (Fig. 2; Table S2 in the Supplement). Discrepancies between the ACSM and FRM methods are larger during winter and spring compared to that of summer, and the direction of the discrepancy is different in spring (ACSM $<$ FRM) as compared to winter and summer (ACSM > FRM). This might be due to positive artifacts of the filter sampling method, which are likely enhanced in colder months (Solomon et al., 2003a, b). On the other hand, uncertainties in RIE values may also result in inaccurate ACSM chemical constituent measurements leading to over- or underestimation of ACSM NR-PM 1 mass.

The slope resulting from the intercomparison of ACSM NR-PM $M_{1}$ mass concentration and SEMS $\mathrm{PM}_{1}$ volume concentration can be used to estimate aerosol density. Comparison suggests a slope of 1.59 (Fig. 3); however, this number will be larger when the refractory components (i.e., EC)

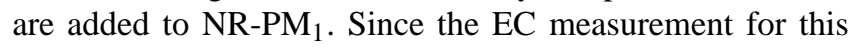
period (October-November 2012) are not available, we estimated that EC contributes about $10 \%$ to total PM based on available data (i.e., October-November 2011). Hence, the estimated aerosol density in Atlanta is $1.75 \mathrm{~g} \mathrm{~cm}^{-3}$ for fall 2012. In addition, we estimated typical dry aerosol density based on average particle composition of $60.1 \%$ of organics, $30.8 \%$ of inorganics, plus $10 \%$ of EC, and the assumption of organic, inorganics, and EC densities are 1.2, 1.77 , and $1.77 \mathrm{~g} \mathrm{~cm}^{-3}$ (Zhang et al., 2005b, and references therein). This approached resulted in typical dry density of $1.61 \mathrm{~g} \mathrm{~cm}^{-3}$. These numbers are consistent with recent ambient aerosol density estimations, such as $1.61 \mathrm{~g} \mathrm{~cm}^{-3}$ in Beijing (Hu et al., 2012) and $1.46 \mathrm{~g} \mathrm{~cm}^{-3}$ in Pasadena (Hayes et al., 2013).

\section{Conclusions}

This study aims to compare species and total mass measurements from the ACSM to the collocated measurements at the JST site (i.e., ACSM, JST continuous and filter samplers, and FRM filters) over different seasons. Mass concentrations obtained from the two ACSMs agree within 4-38\%, except for $\mathrm{Cl}^{-}$. Overall, the percentage differences of ACSM speciated mass concentrations agree within 4-51\% from the SEARCH network measurements, except for $\mathrm{NO}_{3}^{-}$(77-114\%). Comparison of ACSM OM to JST Sunset OC yielded OM/OC ratios of 4.85 and 3.85 for summer and fall periods, respectively. Discrepancies between ACSM PM 1 and TEOM PM 2.5 are $50-110 \%$, while discrepancies between ACSM PM1 and FRM $\mathrm{PM}_{1}$ are 10-73\%. Estimated aerosol density based on ratio of mass to volume concentration is $1.75 \mathrm{~g} \mathrm{~cm}^{-3}$.

Discrepancies found in the intercomparisons of the ACSM and the collocated measurements might be explained by the following: (1) RIE values of organics might have dependencies on sources of organic aerosol; (2) possible interferences from organic and organic-nitrate-specific fragments to the $m / z 30$ ion signal that constitute ACSM inorganic $\mathrm{NO}_{3}^{-}$signal; and (3) evaporative losses of semi-volatile species from the filter measurements used in the collocated continuous measurement adjustment. Future work should systematically examine all of the possibilities. Additionally, calibration of the continuous instruments used at monitoring sites should also be routinely checked with a standard aerosol in addition to the standard gas calibration that is typically performed.

\section{The Supplement related to this article is available online at doi:10.5194/amt-7-1929-2014-supplement.}

Acknowledgements. We thank the Electric Power Research Institute (EPRI) for their support. We thank Jerry Brown and Mike Boaz of Atmospheric Research and Analysis (ARA) for their maintenance of the ACSM at the JST site. We thank Fred Brechtel for his input on SEM-MCPC operation and data analysis. S. H. Budisulistiorini is supported by a Fulbright Presidential Fellowship (2010-2013) for attending the University of North Carolina at Chapel Hill. We also thank Wendy Marth for her assistance in setting up the ACSM at the JST site and Sriram Suresh for his assistance in ACSM fitting RIE formula derivation. GIT ACSM measurements were supported by US EPA grant \# RD83479901 as part of the Emory/Georgia Tech Clean Air Center (SCAPE). Regarding the GIT ACSM data; the contents of this paper are solely the responsibility of the grantee and do not necessarily represent the official views of the US EPA. These agencies do not endorse the purchase of any commercial products or services mentioned in the publication.

Edited by: P. Herckes 


\section{References}

Aiken, A. C., DeCarlo, P. F., Kroll, J. H., Worsnop, D. R., Huffman, J. A., Docherty, K. S., Ulbrich, I. M., Mohr, C., Kimmel, J. R., Sueper, D., Sun, Y., Zhang, Q., Trimborn, A., Northway, M., Ziemann, P. J., Canagaratna, M. R., Onasch, T. B., Alfarra, M. R., Prevot, A. S. H., Dommen, J., Duplissy, J., Metzger, A., Baltensperger, U., and Jimenez, J. L.: O/C and OM/OC Ratios of Primary, Secondary, and Ambient Organic Aerosols with HighResolution Time-of-Flight Aerosol Mass Spectrometry, Environ. Sci. Technol., 42, 4478-4485, doi:10.1021/es703009q, 2008.

Alfarra, M. R., Coe, H., Allan, J. D., Bower, K. N., Boudries, H., Canagaratna, M. R., Jimenez, J. L., Jayne, J. T., Garforth, A. A., Li, S., and Worsnop, D. R.: Characterization of urban and rural organic particulate in the Lower Fraser Valley using two Aerodyne Aerosol Mass Spectrometers, Atmos. Environ., 38, 57455758, doi:10.1016/j.atmosenv.2004.01.054, 2004.

Bahreini, R., Ervens, B., Middlebrook, A. M., Warneke, C., de Gouw, J. A., DeCarlo, P. F., Jimenez, J. L., Brock, C. A., Neuman, J. A., Ryerson, T. B., Stark, H., Atlas, E., Brioude, J., Fried, A., Holloway, J. S., Peischl, J., Richter, D., Walega, J., Weibring, P., Wollny, A. G., and Fehsenfeld, F. C.: Organic aerosol formation in urban and industrial plumes near Houston and Dallas, Texas, J. Geophys. Res., 114, D00F16, doi:10.1029/2008JD011493, 2009.

Baumann, K., Ift, F., Zhao, J. Z., and Chameides, W. L.: Discrete measurements of reactive gases and fine particle mass and composition during the 1999 Atlanta Supersite Experiment, J. Geophys. Res., 108, 8416, doi:10.1029/2001JD001210, 2003.

Canagaratna, M. R., Jayne, J. T., Jimenez, J. L., Allan, J. D., Alfarra, M. R., Zhang, Q., Onasch, T. B., Drewnick, F., Coe, H., Middlebrook, A., Delia, A., Williams, L. R., Trimborn, A. M., Northway, M. J., DeCarlo, P. F., Kolb, C. E., Davidovits, P., and Worsnop, D. R.: Chemical and microphysical characterization of ambient aerosols with the aerodyne aerosol mass spectrometer, Mass Spectrom. Rev., 26, 185-222, doi:10.1002/mas.20115, 2007.

Code of Federal Regulations: 40 CFR 50, Appendix L to Part 50 Reference method for the determination of fine particulate matter as $\mathrm{PM}_{2.5}$ in the atmosphere. Washington D.C., USA, 2001.

Couvidat, F., Kim, Y., Sartelet, K., Seigneur, C., Marchand, N., and Sciare, J.: Modeling secondary organic aerosol in an urban area: application to Paris, France, Atmos. Chem. Phys., 13, 983-996, doi:10.5194/acp-13-983-2013, 2013.

Dockery, D. W., Pope, C. A., Xu, X., Spengler, J. D., Ware, J. H., Fay, M. E., Ferris, B. G., and Speizer, F. E.: An Association between Air Pollution and Mortality in Six U.S. Cities, N. Engl. J. Med., 329, 1753-1759, doi:10.1056/NEJM199312093292401, 1993.

Edgerton, E. S., Hartsell, B. E., Saylor, R. D., Jansen, J. J., Hansen, D. A., and Hidy, G.M.: The Southeastern Aerosol Research and Characterization Study: Part II. Filter-Based Measurements of Fine and Coarse Particulate Matter Mass and Composition, J. Air Waste Manage., 55, 1527-1542, 2005.

Edgerton, E. S., Hartsell, B. E., Saylor, R. D., Jansen, J. J., Hansen, D. A., and Hidy, G. M.: The Southeastern Aerosol Research and Characterization Study, Part 3: Continuous Measurements of Fine Particulate Matter Mass and Composition, J. Air Waste Manage., 56, 1325-1341, 2006.
El-Zanan, H., Hansen, D. A., Mazzoleni, L. R., and Zielinska, B.: Analytical determination of the aerosol organic massto-organic carbon ratio, J. Air Waste Manage., 59, 58-69, doi:10.3155/1047-3289.59.1.58, 2009.

Fröhlich, R., Cubison, M. J., Slowik, J. G., Bukowiecki, N., Prévôt, A. S. H., Baltensperger, U., Schneider, J., Kimmel, J. R., Gonin, M., Rohner, U., Worsnop, D. R., and Jayne, J. T.: The ToF-ACSM: a portable aerosol chemical speciation monitor with TOFMS detection, Atmos. Meas. Tech., 6, 3225-3241, doi:10.5194/amt-6-3225-2013, 2013.

Gard, E., Mayer, J. E., Morrical, B. D., Dienes, T., Fergenson, D. P., and Prather, K. A.: Real-Time Analysis of Individual Atmospheric Aerosol Particles: Design and Performance of a Portable ATOFMS, Anal. Chem., 69, 4083-4091, doi:10.1021/ac970540n, 1997.

Grover, B. D., Kleinman, M., Eatough, N. L., Eatough, D. J., Cary, R. A., Hopke, P. K., and Wilson, W. E.: Measurement of Fine Particulate Matter Nonvolatile and Semi-Volatile Organic Material with the Sunset Laboratory Carbon Aerosol Monitor, J. Air Waste Manage., 58, 72-77, doi:10.3155/1047-3289.58.1.72, 2008.

Hansen, D. A., Edgerton, E. S., Hartsell, B. E., Jansen, J. J., Kandasamy, N., Hidy, G. M., and Blanchard, C. L.: The Southeastern Aerosol Research and Characterization Study: Part 1-Overview, J. Air Waste Manage., 53, 1460-1471, doi:10.1080/10473289.2003.10466318, 2003.

Hayes, P. L., Ortega, A. M., Cubison, M. J., Froyd, K. D., Zhao, Y., Cliff, S. S., Hu, W. W., Toohey, D. W., Flynn, J. H., Lefer, B. L., Grossberg, N., Alvarez, S., Rappenglück, B., Taylor, J. W., Allan, J. D., Holloway, J. S., Gilman, J. B., Kuster, W. C., de Gouw, J. A., Massoli, P., Zhang, X., Liu, J., Weber, R. J., Corrigan, A. L., Russell, L. M., Isaacman, G., Worton, D. R., Kreisberg, N. M., Goldstein, A. H., Thalman, R., Waxman, E. M., Volkamer, R., Lin, Y. H., Surratt, J. D., Kleindienst, T. E., Offenberg, J. H., Dusanter, S., Griffith, S., Stevens, P. S., Brioude, J., Angevine, W. M., and Jimenez, J. L.: Organic aerosol composition and sources in Pasadena, California during the 2010 CalNex campaign, J. Geophys. Res., 118, 9233-9233, doi:10.1002/jgrd.50530, 2013.

Hennigan, C. J., Sullivan, A. P., Fountoukis, C. I., Nenes, A., Hecobian, A., Vargas, O., Peltier, R. E., Case Hanks, A. T., Huey, L. G., Lefer, B. L., Russell, A. G., and Weber, R. J.: On the volatility and production mechanisms of newly formed nitrate and water soluble organic aerosol in Mexico City, Atmos. Chem. Phys., 8, 3761-3768, doi:10.5194/acp-8-3761-2008, 2008.

Hering, S. and Cass, G.: The Magnitude of Bias in the Measurement of PM25 Arising from Volatilization of Particulate Nitrate from Teflon Filters, J. Air Waste Manage., 49, 725-733, doi:10.1080/10473289.1999.10463843, 1999.

Hu, M., Peng, J., Sun, K., Yue, D., Guo, S., Wiedensohler, A., and Wu, Z.: Estimation of Size-Resolved Ambient Particle Density Based on the Measurement of Aerosol Number, Mass, and Chemical Size Distributions in the Winter in Beijing, Environ. Sci. Technol., 46, 9941-9947, doi:10.1021/es204073t, 2012.

IPCC: Summary for Policymakers, in: Climate Change 2013: The Physical Science Basis, Contribution of Working Group I to the Fifth Assessment Report of the Intergovernmental Panel on Climate Change, Cambridge University Press, Cambridge, United Kingdom and New York, NY, USA, 2013. 
Jayne, J. T., Leard, D. C., Zhang, X., Davidovits, P., Smith, K. A., Kolb, C. E., and Worsnop, D. R.: Development of an Aerosol Mass Spectrometer for Size and Composition Analysis of Submicron Particles, Aerosol Sci. Technol., 33, 49-70, 2000.

Jimenez, J. L., Jayne, J. T., Shi, Q., Kolb, C. E., Worsnop, D. R., Yourshaw, I., Seinfeld, J. H., Flagan, R. C., Zhang, X., Smith, K. A., Morris, J. W., and Davidovits, P.: Ambient aerosol sampling using the Aerodyne Aerosol Mass Spectrometer, J. Geophys. Res., 108, 8425, doi:10.1029/2001JD001213, 2003.

Jimenez, J. L., Canagaratna, M. R., Donahue, N. M., Prevot, A. S. H., Zhang, Q., Kroll, J. H., DeCarlo, P. F., Allan, J. D., Coe, H., Ng, N. L., Aiken, A. C., Docherty, K. S., Ulbrich, I. M., Grieshop, A. P., Robinson, A. L., Duplissy, J., Smith, J. D., Wilson, K. R., Lanz, V. A., Hueglin, C., Sun, Y. L., Tian, J., Laaksonen, A., Raatikainen, T., Rautiainen, J., Vaattovaara, P., Ehn, M., Kulmala, M., Tomlinson, J. M., Collins, D. R., Cubison, M. J. E., Dunlea, J., Huffman, J. A., Onasch, T. B., Alfarra, M. R., Williams, P. I., Bower, K., Kondo, Y., Schneider, J., Drewnick, F., Borrmann, S., Weimer, S., Demerjian, K., Salcedo, D., Cottrell, L., Griffin, R., Takami, A., Miyoshi, T., Hatakeyama, S., Shimono, A., Sun, J. Y., Zhang, Y. M., Dzepina, K., Kimmel, J. R., Sueper, D., Jayne, J. T., Herndon, S. C., Trimborn, A. M., Williams, L. R., Wood, E. C., Middlebrook, A. M., Kolb, C. E., Baltensperger, U., and Worsnop, D. R.: Evolution of Organic Aerosols in the Atmosphere, Science, 326, 1525-1529, doi:10.1126/science.1180353, 2009.

Kleindienst, T. E., Edney, E. O., Lewandowski, M., Offenberg, J. H., and Jaoui, M.: Secondary Organic Carbon and Aerosol Yields from the Irradiations of Isoprene and $\alpha$-Pinene in the Presence of $\mathrm{NO}_{\mathrm{x}}$ and $\mathrm{SO}_{2}$, Environ. Sci. Technol., 40, 3807-3812, doi:10.1021/es052446r, 2006.

Lee, S., Murphy, D. M., Thomson, D. S., and Middlebrook, A. M.: Chemical components of single particles measured with Particle Analysis by Laser Mass Spectrometry (PALMS) during the Atlanta SuperSite Project: Focus on organic/sulfate, lead, soot, and mineral particles, J. Geophys. Res., 107, 4003, doi:10.1029/2000JD000011, 2002.

Lim, H. and Turpin, B. J.: Origins of Primary and Secondary Organic Aerosol in Atlanta: Results of Time-Resolved Measurements during the Atlanta Supersite Experiment, Environ. Sci. Technol., 36, 4489-4496, doi:10.1021/es0206487, 2002.

Lim, H., Turpin, B. J., Edgerton, E., Hering, S. V., Allen, G., Maring, H., and Solomon, P.: Semicontinuous aerosol carbon measurements: Comparison of Atlanta Supersite measurements, J. Geophys. Res., 108, 8419, doi:10.1029/2001JD001214, 2003.

Lin, Y., Zhang, Z., Docherty, K. S., Zhang, H., Budisulistiorini, S. H., Rubitschun, C. L., Shaw, S. L., Knipping, E. M., Edgerton, E. S., Kleindienst, T. E., Gold, A., and Surratt, J. D.: Isoprene Epoxydiols as Precursors to Secondary Organic Aerosol Formation: Acid-Catalyzed Reactive Uptake Studies with Authentic Compounds, Environ. Sci. Technol., 46, 250258, doi:10.1021/es202554c, 2012.

Middlebrook, A. M., Bahreini, R., Jimenez, J. L., and Canagaratna, M. R.: Evaluation of Composition-Dependent Collection Efficiencies for the Aerodyne Aerosol Mass Spectrometer using Field Data, Aerosol Sci. Technol., 46, 258-271, doi:10.1080/02786826.2011.620041, 2012.

Ng, N. L., Herndon, S. C., Trimborn, A., Canagaratna, M. R., Croteau, P. L., Onasch, T. B., Sueper, D., Worsnop, D. R., Zhang,
Q., Sun, Y. L., and Jayne, J. T.: An Aerosol Chemical Speciation Monitor (ACSM) for Routine Monitoring of the Composition and Mass Concentrations of Ambient Aerosol, Aerosol Sci. Technol., 45, 780-794, doi:10.1080/02786826.2011.560211, 2011.

Peltier, R. E., Weber, R. J., and Sullivan, A. P.: Investigating a Liquid-Based Method for Online Organic Carbon Detection in Atmospheric Particles, Aerosol Sci. Technol., 41, 1117-1127, doi:10.1080/02786820701777465, 2007.

Polidori, A.: Organic $\mathrm{PM}_{2.5}$ : Fractionation by Polarity, FTIR Spectroscopy, and OM / OC Ratio for the Pittsburgh Aerosol, Aerosol Sci. Technol., 42, 233-246, doi:10.1080/02786820801958767, 2008.

Rastogi, N., Zhang, X., Edgerton, E. S., Ingall, E., and Weber, R. J.: Filterable water-soluble organic nitrogen in fine particles over the southeastern USA during summer, Atmos. Environ., 45, 60406047, doi:10.1016/j.atmosenv.2011.07.045, 2011.

Russell, L. M.: Aerosol Organic-Mass-to-Organic-Carbon Ratio Measurements, Environ. Sci. Technol., 37, 2982-2987, doi:10.1021/es026123w, 2003.

Schwab, J. J., Hogrefe, O., Demerjian, K. L., Dutkiewicz, V. A., Husain, L., Rattigan, O. V., and Felton, H. D.: Field and laboratory evaluation of the Thermo Electron 5020 Sulfate Particulate Analyzer, Aerosol Sci. Technol., 40, 744-752, doi:10.1080/02786820500529414, 2006.

Solomon, P. A., Chameides, W., Weber, R., Middlebrook, A., Kiang, C. S., Russell, A. G., Butler, A., Turpin, B., Mikel, D., Scheffe, R., Cowling, E., Edgerton, E., St. John, J., Jansen, J., McMurry, P., Hering, S., and Bahadori, T.: Overview of the 1999 Atlanta Supersite Project, J. Geophys. Res., 108, 8413, doi:10.1029/2001JD001458, 2003a.

Solomon, P., Baumann, K., Edgerton, E., Tanner, R., Eatough, D., Modey, W., Maring, H., Savoie, D., Natarajan, S., Meyer, M. B., and Norris, G.: Comparison of integrated samplers for mass and composition during the 1999 Atlanta Supersites project, J. Geophys. Res., 108, 8423, doi:10.1029/2001JD001218, 2003 b.

Sorooshian, A., Hersey, S., Brechtel, F. J., Corless, A., Flagan, R. C., and Seinfeld, J. H.: Rapid, size-resolved aerosol hygroscopic growth measurements: Differential aerosol sizing and hygroscopicity spectrometer probe (DASH-SP), Aerosol Science and Technology, Aerosol. Sci. Technol., 42, 445-464, 2008.

Sun, Y., Wang, Z., Dong, H., Yang, T., Li, J., Pan, X., Chen, P., and Jayne, J. T.: Characterization of summer organic and inorganic aerosols in Beijing, China with an Aerosol Chemical Speciation Monitor, Atmos. Environ., 51, 250-259, doi:10.1016/j.atmosenv.2012.01.013, 2012.

Sun, Y.-L., Zhang, Q., Schwab, J. J., Demerjian, K. L., Chen, W.N., Bae, M.-S., Hung, H.-M., Hogrefe, O., Frank, B., Rattigan, O. V., and Lin, Y.-C.: Characterization of the sources and processes of organic and inorganic aerosols in New York city with a high-resolution time-of-flight aerosol mass apectrometer, Atmos. Chem. Phys., 11, 1581-1602, doi:10.5194/acp-11-15812011, 2011.

Takegawa, N., Miyazaki, Y., Kondo, Y., Komazaki, Y., Miyakawa, T., Jimenez, J. L., Jayne, J. T., Worsnop, D. R., Allan, J. D., and Weber, R. J.: Characterization of an Aerodyne Aerosol Mass Spectrometer (AMS): Intercomparison with Other Aerosol Instruments, Aerosol Sci. Technol., 39, 760-770, doi:10.1080/02786820500243404, 2005. 
Turpin, B. J. and Lim, H. J.: Species Contributions to PM2.5 Mass Concentrations: Revisiting Common Assumptions for Estimating Organic Mass, Aerosol Sci. Technol., 35, 602-610, doi:10.1080/02786820119445, 2001.

Weber, R., Bergin, M., Kiang, C. S., Chameides, W., Orsini, D., St, J. J., Chang, M., Bergin, M., Carrico, C., Lee, Y. N., Dasgupta, P., Slanina, J., Turpin, B., Edgerton, E., Hering, S., Allen, G., and Solomon, P.: Short-term temporal variation in PM2.5 mass and chemical composition during the Atlanta Supersite Experiment, 1999, J. Air Waste Manage., 53, 84-91, 2003a.

Weber, R., Orsini, D., Duan, Y., Baumann, K., Kiang, C. S., Chameides, W., Lee, Y. N., Brechtel, F., Klotz, P., Jongejan, P., ten Brink, H., Slanina, J., Boring, C. B., Genfa, Z., Dasgupta, P., Hering, S., Stolzenburg, M., Dutcher, D. D., Edgerton, E., Hartsell, B., Solomon, P., and Tanner, R.: Intercomparison of near real time monitors of $\mathrm{PM}_{2.5}$ nitrate and sulfate at the U.S. Environmental Protection Agency Atlanta Supersite, J. Geophys. Res., 108, 8421, doi:10.1029/2001JD001220, 2003b.
Zhang, Q., Worsnop, D. R., Canagaratna, M. R., and Jimenez, J. L.: Hydrocarbon-like and oxygenated organic aerosols in Pittsburgh: insights into sources and processes of organic aerosols, Atmos. Chem. Phys., 5, 3289-3311, doi:10.5194/acp-5-32892005, 2005a.

Zhang, Q., Canagaratna, M. R., Jayne, J. T., Worsnop, D. R., and Jimenez, J.: Time- and size-resolved chemical composition of submicron particles in Pittsburgh: Implications for aerosol sources and processes, J. Geophys. Res., 110, D07S09, doi:10.1029/2004JD004649, 2005b. 